\title{
Immunolocalization of Morphogen Sonic Hedgehog in Salmon Fry (Salmo salar)
}

\author{
Inmunolocalización del Morfógeno Sonic Hedhehog en Alevines de Salmón (Salmo salar)
}

\author{
Mariana Rojas,*;*; Gustavo Saint-Pierre**; Ricardo Hartley ${ }^{* *, * * * ;}$ \\ Bélgica Vásquez ${ }^{* * * *}$; Daniel Conei ${ }^{*, * * * * *}$ \& Mariano del Sol ${ }^{*, * * * * * * *}$
}

ROJAS, M.; SAINT-PIERRE, G.; HARTLEY, R.; VÁSQUEZ, B.; CONEI, D. \& DEL SOL, M. Immunolocalization of morphogen sonic hedgehog in salmon fry (Salmo salar). Int. J. Morphol., 34(2):770-774, 2016.

SUMMARY: With the purpose of carrying out a diagnosis of the different pathologies that affect the salmon fry stage (Salmo salar) and analyze the regeneration phases of the organizational centers and subjacent tissue in case of an amputation, we realized a study that allowed identifying the temporary and spatial location of the Sonic Hedgehog (Shh) morphogen in hatched fry stage. Fifteen salmon fry (Salmo salar) were used. They were anesthetized with $5 \%$ benzocaine (BZ-20 ${ }^{\circledR}$, Veterquímica), fixed in $10 \%$ buffered formalin, and embedded in paraffin, Shh polyclonal antibody (Santa Cruz H-160, rabbit) was used diluted at 1/100. They were subsequently rinsed in PBS-1\% Triton and incubated with anti-rabbit conjugated polymer antibody and HRP for 10-15 min. The development was done with DAB (Vector) for 1-5 min. The negative control was incubated without primary antibody. As an internal positive control the notochord was considered. Serial sagittal sections were analyzed consigning tissues and organs marked positively and were described morphologically. The objective of recognizing the spatial and temporal location of Shh was achieved. The notochord, spinal cord neurons and ganglia, the basal layer of the skin and also the lepidotriquias escleroblastos were positively identified for Shh. Finally positivity was also observed in the intestine and renal tubules. The heterogeneity observed in the location of the Shh morphogen suggests its potential use as a marker of regulatory centers in Salmo salar, and a potential advantage in the diagnosis of malformations of salmon fry stage, in addition to a better understanding of tissue regeneration.

KEY WORDS: Sonic hedgehog; Salmon fry; Immunohistochemistry; Antibody antiShh

\section{INTRODUCTION}

Shh is a gene involved in different processes of embryonic development, as the induction of the neural tube, differentiation of the somites, and regionalization of the intestine (Sadler, 2012), it is also related to a center of signals involved in the anteroposterior formation members design (Johnson et al., 1994; Antonelli et al., 2012). The Shh gene is highly conserved and has been identified both in humans and in animal models: drosophila, zebrafish, chicken, xenopus and mouse (Rathnam, 2007).

The Shh protein is a signaling molecule that acts as a morphogen. The term applies to a molecule organic nature which is produced and secreted by a group of embryonic cells and can diffuse and act remotely on other cells or tissues (Gurdon \& Bourillot, 2001; Tabata \& Takei, 2004; Rojas et al., 2014a).

Shh expression being restricted to the regions of the embryo with organizing activity (Krauss et al., 1993; Strähle et al., 1996; Scholpp et al., 2006). In mammalian embryos, there are cell groups located in the notochord, floor plate of the neural tube and zone of polarizing activity of the limb. This morphogen diffuses neighboring cells to form a concentration gradient over a threshold which triggers the expression of various genes involved in cell and tissue specification (Wolpert, 2009; Rojas et al., 2014a,b).

* Doctoral Program in Morphological Sciences, Universidad de La Frontera, Temuco, Chile.

** Comparative Embryology Laboratory, Program of Anatomy and Developmental Biology, ICBM,Faculty of Medicine,Universidad de Chile, Chile.

*** Laboratorio de Criobiología y Análisis de Funcionalidad Espermática, Instituto de Ciencia Animal, Facultad de Ciencias Veterinarias, Universidad Austral de Chile, Valdivia, Chile.

***** Universidad de Tarapacá, Chile.

****** Universidad Espíritu Santo, Guayaquil, Ecuador.

******* Centro de Investigación en Ciencias Biomédicas, Universidad Autónoma de Chile, Temuco, Chile. 
The Shh protein has a highly conserved N-terminal region and a more variable $\mathrm{C}$-terminal region (Calson, 2014). After synthesis and release from the rough endoplasmic reticulum, the signal peptide is fragmented and the remaining peptide is glycosylated. Inside the cell the peptide Shh undergoes self-fragmentation by the catalytic activity of the C-terminal portion. During this fragmentation, the $\mathrm{N}$-terminal segment is joined covalently to cholesterol. The $\mathrm{N}$-terminal peptide is secreted by the cell but remains attached to the surface thereof. By the activity of another gene product $\mathrm{N}$-terminal segment is finally released from the cell. All signaling activity resides in the N-terminal segment (Carlson).

Regarding the pathologies, it has been observed that the decreased expression of Shh in human embryos can cause holoprosencephaly, polydactyly, craniofacial defects and skeletal malformations (Roessler et al., 1996; Muenke \& Beachy, 2000; McMahon et al., 2003). Alterations in the expression and activity of Shh is responsible for basal cell carcinoma and rhabdomyosarcoma cells (Bale \& Yu, 2001; Pasca di Magliano \& Hebrok, 2003; Stecca \& Altaba, 2005), mice with mutations Shh are cyclops.

Knowledge of the location of the expression of Shh can become a tool for studying the development of fish. In the case of salmonid, its cultivation is of great economic importance for Chile, we must have a knowledge of this morphogen expression, especially in the nursery stage for better diagnosis of various pathologies of the neural tube, eye and spine (Sanchez et al., 2011; Hernández \& Rojas, 2013) as well as providing information for understanding the phases of regeneration of tissues when they have been amputated.

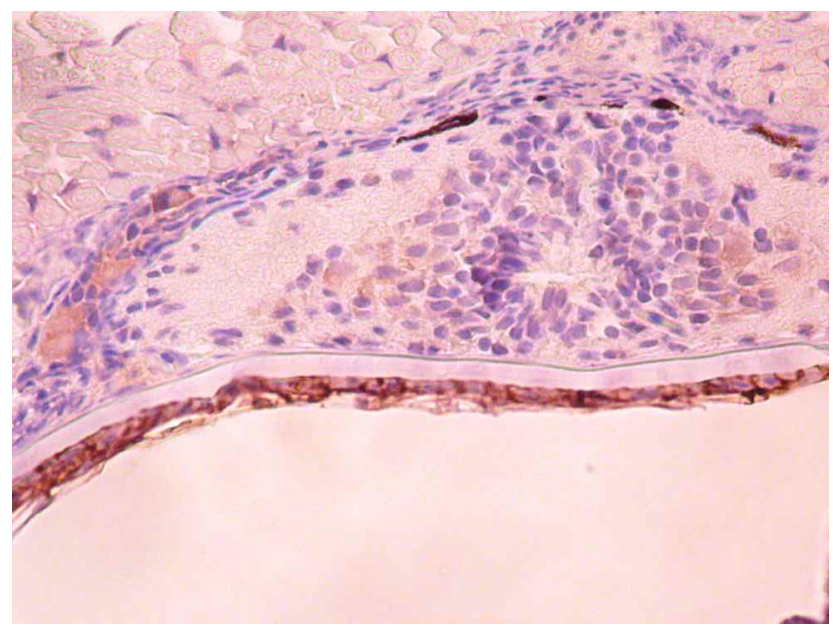

Fig. 1. Cross section of spinal cord and notochord. The notochord chromogen stained brown color. The cytoplasm of neurons in the mantle layer is weakly stained. Anti Shh, 400X.
This study aimed to know the spatial and temporal location of Shh in salmon fry, particularly in the notochord, neural tube, retina, skeletal muscle walls of the body, skin, and fins. Salmon have the ability to regenerate fins, spinal cord, retina even in the adult stage, we believe signaling centers as the notochord retain the ability to produce these morphogens even after hatching and hope to find positive immunostaining of Shh in juvenile stages. This knowledge will be useful for use in the diagnosis of congenital malformations and in studies of tissue regeneration because Shh expression is restricted to regions with organizer and signaling activity.

\section{MATERIAL AND METHOD}

Fifteen salmon fry were used. They were anesthetized with $5 \%$ benzocaine (BZ-20 ${ }^{\circledR}$, Veterquímica) The study was approved by the Scientific Ethics Committee of the Universidad de La Frontera, Chile.

After obtaining the fry salmon, they were fixed in 10 $\%$ buffered formalin, and embedded in paraffin. Sections of $5 \mu \mathrm{m}$ were obtained with Microm microtome (HM315R) which adhered to positively charged slides (Citoglas). Five sections per slide were attached, considering a total of 2 slides per juvenile. Antigen retrieval was performed in steamer for 40 min, with sections immersed in Antigen unmasking solution (Vector), blocking of endogenous peroxidase was performed with hydrogen peroxide in methanol and blocking nonspecific protein with PBS $+3 \%$ BSA. For incubation with Shh primary antibody (Santa Cruz H-160, rabbit) dilution 1/100 was used. For detection of the primary antibody it was incubated with polymer conjugated with HRP anti rabbit antibody for $15 \mathrm{~min}$. As substrate diaminobenzidine (DAB, Vector Labs) was used.

The negative control was given by the complete development of immunohistochemical technique, but excluding the primary antibodies. As an internal positive control the notochord was considered. Serial sagittal fish sections were analyzed consigning tissues and organs that were marked positively and were described morphologically.

\section{RESULTS}

The antibody anti-Shh used was reactive in salmon fry. Strongly positive immunostaining was observed in the notochord. Motor neurons located near the notochord were observed weakly stained (Figs. 1, 2 and 3). 
The retina presented positive staining in cells of the ganglion and inner nuclear layer (Fig. 4). The vertebral spine was characterized by hyaline cartilage with few positive chondrocytes, strongly positive striated muscle fibers were observed. The connective tissue was negative (Fig. 3). The basal layer of the epithelium lining was positive (Figs. 3 and 5).

In the caudal fin (Figs. 5 and 6) labeled cells were found in the basal layer of the epithelium as well as in the lepidotriquias escleroblastos. Both blastema rays as interray of blood vessels had very stained lumen, but the endothelium was unmarked.

Among the organs the intestinal loops and the renal tubules were highlighted as positive.

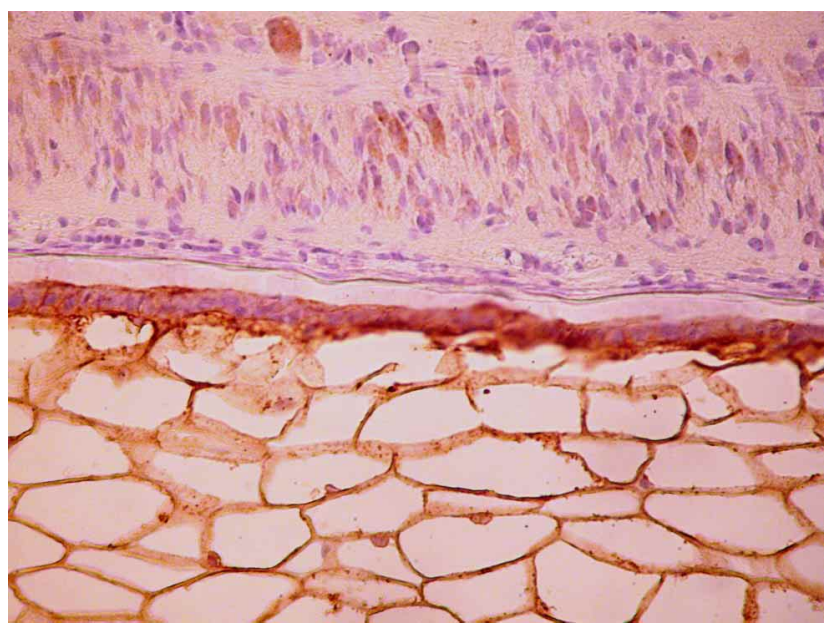

Fig. 2. Sagittal section of notochord constituted by a layer of cordoblastic cells and intensely positive vacuolated cells. Weakly stained neurons. Anti-Shh, 400X.

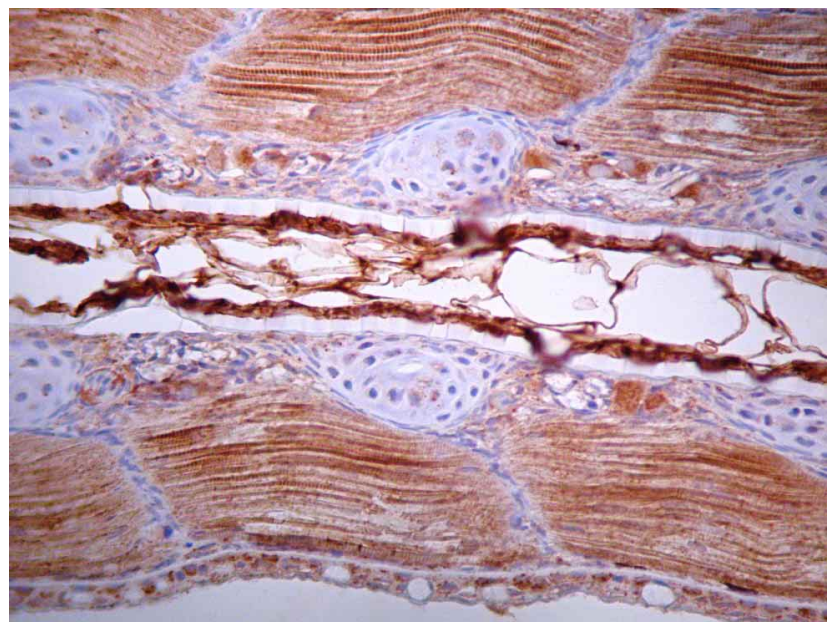

Fig. 3. Sagittal section Notochord level. Hyaline cartilage with some marked chondrocytes, striated muscle fibers intensely positive. Lining epithelium positive. Anti-Shh, 400X.

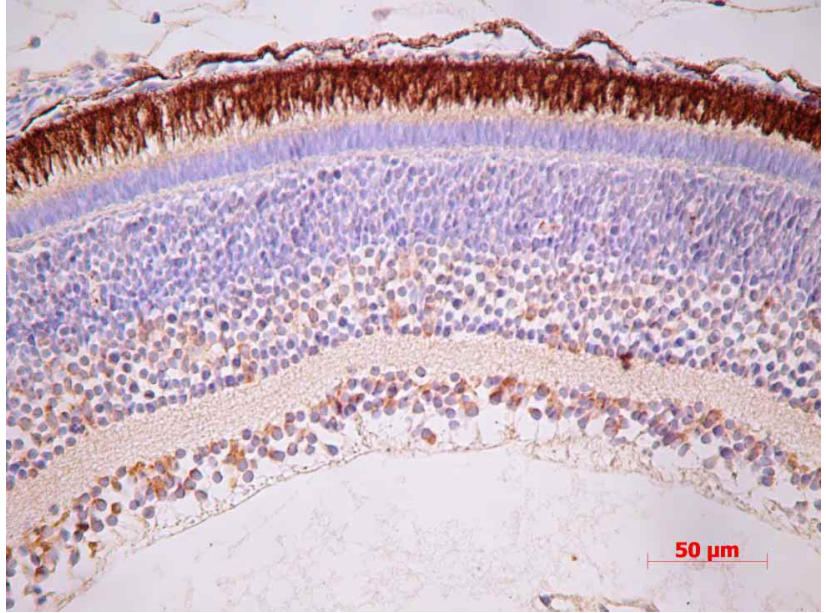

Fig. 4. Sagittal section level retina. The nodal layers and the inner nuclear have cytoplasm of positive cells. The pigment layer does not correspond to positive immunostaining because it appears equally dyed in the negative control. Anti-Shh.

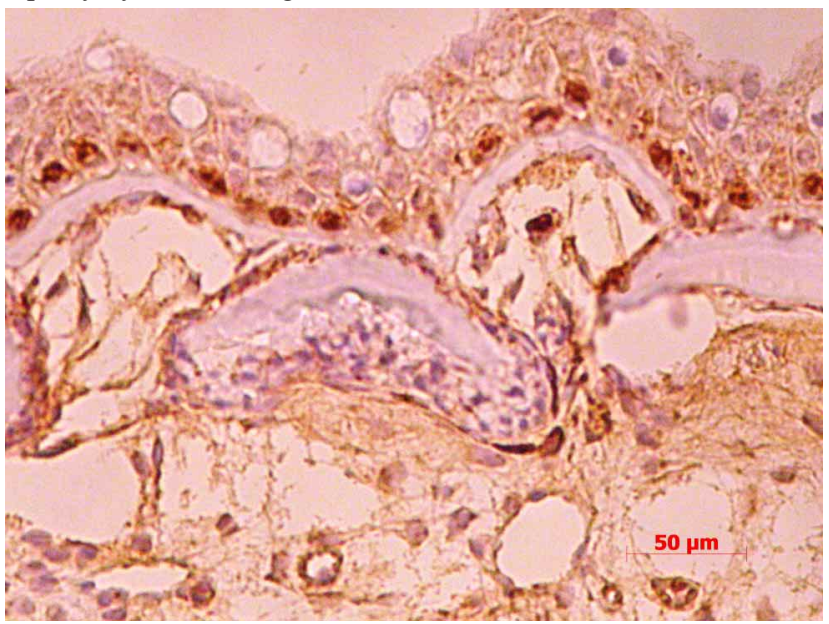

Fig. 5. Cross section caudal level. Basal layer of the epithelium lining intensely stained lepidotriquias, escleroblastos positive rays. Anti-Shh.

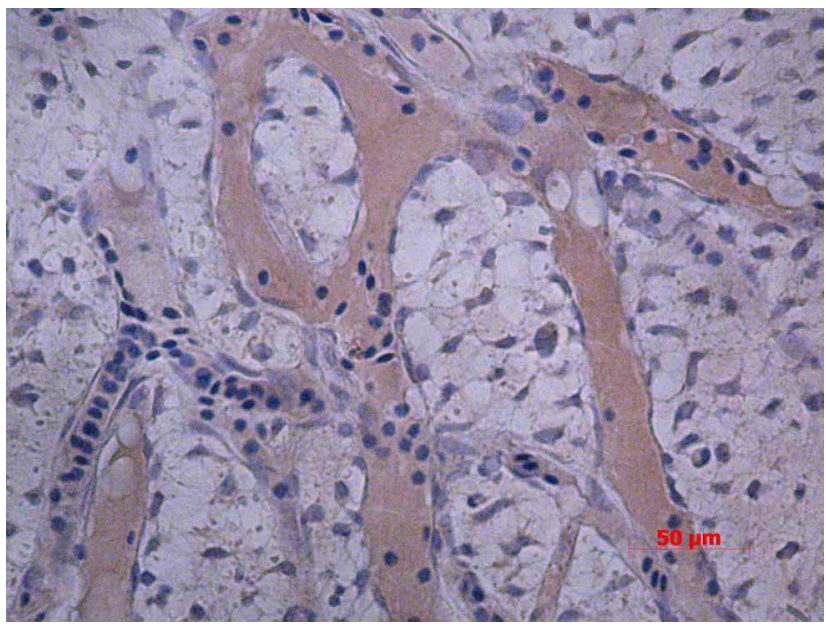

Fig. 6. Sagittal section level caudal fin of fry subjected to hypoxia. Irregular blood vessels, angiogenesis in various orientations. Negative endothelial cells, lumen stark. Anti-Shh. 


\section{DISCUSSION}

The presence of Shh was immunohistochemically identified in the notochord, and motor neurons of the spinal cord. An intense labeling was observed in the notochord, which is the signaling center or source of morphogen production and was decreasing towards the neighboring tissues (neural tube neurons). This relates to the information provided by Tabata $\&$ Takei and Kanodia et al., (2011), who indicate that a gradient of Shh signaling regulates the differential expression of genes in a manner dependent on the concentration and it provides a basis for understanding many processes modeling the embryonic body.

When Shh is synthesized by the notochordal cells, it not only controls cell fate of neurons in the neural tube, ventral location so that they can be identified as motor neurons, but also participates in determining the sclerotome and pattern formation of somites (Bumcrot \& McMahon, 1995; Munsterberg \& Lassar, 2005; Lassar \& Munsterberg, 1996). Shh somite triggers differentiation in sclerotome (Fan \& Tessier-Lavigne, 1994; Johnson et al.; Wolpert; Rojas et al., 2014b) which will eventually form the cartilage and bones of the spine (Carlson). In the salmon after hatching, we detect an intense expression in striated stage larva muscle fibers similar to that observed by Blagden et al., (1997) in zebrafish, it could be that the ontogenetic development of many organs and tissues occurs after hatching.

Two layers of the retina showed immunopositive cells. The retina has six classes of neurons and glial cell types which are arranged in layers (Wawersik \& Maas, 2000). In our study only two layers of the retina showed immunopositive cells with cytoplasmic brand. They are the ganglion layer and inner nuclear layer. All these cells are derived from multipotent stem cells (Holt et al., 1988; Wetts \& Fraser, 1988; Turner et al., 1990; Livesey $\&$ Cepko, 2001). Conversely, the outer nuclear layer or rods and cones and receivers pigment epithelium are negative.

In the fins, immunogenicity was observed in the basal layer of the epithelium lining and also in the lepidotriquias escleroblastos. This relates to studies of Wargelius et al. (2009), suggest that Shh can be used as a marker for osteoblast proliferation. The endothelium of blood vessels was negative but the lumen was very strong, this label does not match because endogenous peroxidase was blocked with perhydrol. Positive immunostaining was also found in the intestine and renal tubules.

\section{CONCLUSIONS}

The specific location with anti-Shh emerged as an important marker of signal centers and the gradient of the morphogen in various tissues of salmon fry, it was also possible to recognize the temporal and spatial morphogen with an unquestionable utility in the diagnosis of malformations in salmon fry and greater knowledge of tissue regeneration.

ROJAS, M.; SAINT-PIERRE, G.; HARTLEY, R.; VÁSQUEZ, B.; CONEY, D. \& DEL SOL, M. Inmunolocalización del morfógeno Sonic Hedhehog en alevines de salmón (Salmo salar). Int. J. Morphol., 34(2):770-774, 2016.

RESUMEN: Con el fin de llevar a cabo un diagnóstico de las diferentes patologías que afectan a la etapa de alevín de salmón (Salmo salar) y analizar las fases de regeneración de los centros de organización y el tejido subyacente en caso de una amputación, se realizó un estudio que permitió identificar la ubicación temporal y espacial del morfógeno Sonic hedgehog (Shh) en la etapa de alevines eclosionados. Se utilizaron quince alevines de salmón (Salmo salar). Fueron anestesiados con benzocaína al 5\% (BZ$20 ®$, Veterquímica), se fijaron en formalina tamponada al 10\%, e incluidos en paraplast. Se utilizó Shh anticuerpo policlonal (Santa Cruz H-160, conejo) dilución 1/100. Se enjuagaron posteriormente en PBS-1\% Triton y se incubaron con anticuerpo conjugado con polímero anti-conejo y HRP durante 10-15 minutos. Se utilizó como sustrato DAB (Vector) durante 1-5 minutos. El control negativo se incubó sin anticuerpo primario. Como un control positivo interno se consideró la notocorda. Se analizaron secciones sagitales en serie consignando los tejidos y órganos marcados positivamente y se describieron morfológicamente. Se logró el objetivo de reconocer la localización espacial y temporal de Shh. La notocorda, las neuronas de la médula espinal y los ganglios, la capa basal de la piel y también los escleroblastos de las lepidotriquias fueron identificados positivamente para Shh. También se observó positivo el intestino y los túbulos renales. La heterogeneidad observada en la ubicación del morfógeno Shh sugiere su uso potencial como un marcador de los centros de regulación en Salmo salar, y una ventaja potencial en el diagnóstico de las malformaciones de la etapa de alevines de salmón, además de una mejor comprensión de la regeneración de tejidos.

PALABRAS CLAVE: Sonic hedgehog; alevín de salmón; immunohistoquímica; anticuerpo antiShh.

\section{REFERENCES}

Antonelli, M.; Rosas, C. \& Rojas, M. Desarrollo de los miembros en los vertebrados. Int. J. Morphol., 30(4):1512-9, 2012.

Bale, A. E. \& Yu, K. P. The hedgehog pathway and basal cell carcinomas. Hum. Mol. Genet., 10:757-62, 2001. 
Blagden, C. S.; Currie, P. D.; Ingham, P. W. \& Hughes, S. M. Notochord induction of zebrafish slow muscle mediated by Sonic hedgehog. Genes Dev., 11, 2163-75, 1997.

Bumcrot, D. A. \& McMahon, A. P. Somite differentiation. Sonic signals somites. Curr. Biol. 5:612-4, 1995.

Carlson, B. M. Embriología humana y biología del desarrollo. $5^{\text {th }}$ ed. Madrid, Elsevier España, 2014.

Fan, C. M. \& Tessier-Lavigne, M. Patterning of mammalian somites by the surface ectoderm and the notochord: Evidence for sclerotome induction by Sonic hedgehog/Vhh-1. Cell, 79:1175-86, 1994.

Gurdon, J. B. \& Bourillot, P. Y. Morphogen gradient interpretation. Nature, 413:797-803, 2001.

Hernández, H. \& Rojas, M. Desarrollo de la médula espinal de Salmón (Salmo salar) durante el período post-eclosional. Int. J. Morphol., 31(1):172-6, 2013,

Holt, C. E.; Bertsch, T. W.; Ellis, H. M. \& Harris, W. A. Cellular determination in the Xenopus retina is independent of lineage and birth date. Neuron, 1:15-26, 1988.

Johnson, R. L.; Riddle, R. D.; Laufer, E. \& Tabin, C. Sonic hedgehog: a key mediator of anterior-posterior patterning of the limb and dorsoventral patterning of axial embryonic structures. Biochem. Soc. Trans. 22:569-574, 1994

Kanodia, J. S.; Kim, Y.; Tomer, R.; Khan, Z.; Chung, K.; Storey, J. D.; Lu, H.; Keller, P. J. \& Shvartsman, S. Y. A computational statistics approach for estimating the spatial range of morphogen gradients. Development, 138:4867-74, 2011.

Krauss, S.; Concordet, J. P. \& Ingham, P. W. A functionally conserved homolog of the Drosophila segment polarity gene hh is expressed in tissues with polarizing activity in zebrafish embryos. Cell, 75:1431-44, 1993.

Lassar, A. B. \& Munsterberg, A. E.The role of positive and negative signals in somite patterning. Curr. Opin. Neurobiol., 6:57-63, 1996.

Livesey, F. J. \& Cepko, C. L. Vertebrate neural cell-fate determination: lessons from the retina. Nat. Rev. Neurosci., 2: 109-18, 2001.

McMahon, A. P.; Ingham, P. W. \&Tabin, C. J. Developmental roles and clinical significance of hedgehog signaling. Curr. Top. Dev. Biol., 53:1-114, 2003,

Muenke, M. \& Beachy, P. A. Genetics of ventral forebrain development and holoprosencephaly. Curr. Opin. Genet. Dev. 10:262-9, 2000.

Münsterberg, A. E. \& Lassar, A. B. Combinatorial signals from the neural tube, floor plate and notochord induce myogenic bHLH gene expression in the somite. Development, 121:651-60, 2005.

Pasca di Magliano, M. \& Hebrok, M. Hedgehog signalling in cancer formation and maintenance. Nat. Rev. Cancer, 3:903-11, 2003.

Rathnam, S. Regulation of Sonic hedgehog (Shh) expression in the zebrafish retina. Dissertation Saradavey Rathnam, 2007.
Roessler, E.; Belloni, E.; Gaudenz, K.; Jay, P.;Berta, P.; Scherer, S. W. Tsui, L. C. \& Muenke, M. Mutations in the human Sonic Hedgehog gene cause holoprosencephaly. Nat. Genet. 14:35760, 1996.

Rojas, M.; Signore, I. A. \& Mejias, R. Morfógenos durante el desarrollo embrionario de vertebrados. Int. J. Morphol., 32(1):319-26, 2014b.

Rojas, M. \& Smok, C. Modelando el cuerpo del embrión durante el período somítico. Int. J. Med. Surg. Sci., 1:57-62, 2014 a.

Sadler, T. W. Embriología médica. $12^{\text {nd }}$ ed. Madrid Wolters Klugger/ Lippincott \& Wilkins, 2012.

Sánchez, R. C.; Obregon, E. B. \& Rauco, M. R. Hypoxia is like an ethiological factor in vertebral column deformity of salmon (Salmo salar). Aquaculture, 316:13-9, 2011.

Scholpp, S.; Wolf, O.; Brand, M. \& Lumsden, A. Hedgehog signalling from the zona limitans intrathalamica orchestrates patterning of the zebrafish diencephalon. Development, 133: 855-64, 2006.

Stecca, B. \& Altaba, A. R. I. Brain as a paradigm of organ growth: Hedgehog-Gli signaling in neural stem cells and brain tumors. $J$. Neurobiol., 64:476-90, 2005.

Strähle, U.; Blader, P. \& Ingham, P. W. Expression of axial and sonic hedgehog in wildtype and midline defective zebrafish embryos. Int. J. Dev. Biol., 40:929-40, 1996.

Tabata, T. \& Takei, Y. Morphogens, their identification and regulation. Development, 131:703-12, 2004.

Turner, D. L.; Snyder, E. Y. \& Cepko, C. L. Lineage-independent determination of cell type in the embryonic mouse retina. Neuron, 4:833-45, 1990

Wargelius, A.; Fjelldal, P. G.; Nordgarden, U. \& Hansen, T. Continuous light affects mineralization and delays osteoid incorporation in vertebral bone of Atlantic salmon (Salmo salar L.). J. Exp. Biol., 212:656-61, 2009.

Wawersik, S. \& Maas, R. L. Vertebrate eye development as modeled in Drosophila. Hum. Mol. Genet., 9:917-25, 2000.

Wetts, R. \& Fraser, S. E.Multipotent precursors can give rise to all major cell types of the frog retina. Science, 239:1142-5, 1988.

Wolpert, L. Principios del Desarrollo. $3^{\text {th }}$ ed. Madrid, Médica Panamericana. 2009.

Dirección para Correspondencia:

Dr. Mariano del Sol

Facultad Medicina

Universidad de La Frontera

Temuco - CHILE

Received: 12-03-2016

Accepted: 21-05-2016

E-mail: mariano.delsol@ufrontera.cl 